Key Words:

Gasket

Hanford

Retention:

Permanent

\title{
DEVELOPMENT OF REMOTE HANFORD CONNECTOR GASKET REPLACEMENT TOOLING FOR DWPF
}

\author{
Jeff Coughlin
}

Dan Krementz

DECEMBER 2008

Savannah River National Laboratory

Savannah River Nuclear Solutions

Aiken, SC 29808 


\section{DISCLAIMER}

This work was prepared under an agreement with and funded by the U.S. Government. Neither the U. S. Government or its employees, nor any of its contractors, subcontractors or their employees, makes any express or implied:

1. warranty or assumes any legal liability for the accuracy, completeness, or for the use or results of such use of any information, product, or process disclosed; or

2. representation that such use or results of such use would not infringe privately owned rights; or

3. endorsement or recommendation of any specifically identified commercial product, process, or service.

Any views and opinions of authors expressed in this work do not necessarily state or reflect those of the United States Government, or its contractors, or subcontractors.

Printed in the United States of America

Prepared for

U.S. Department of Energy 
Key Words:

Gasket

Hanford

Retention:

Permanent

\title{
DEVELOPMENT OF REMOTE HANFORD CONNECTOR GASKET REPLACEMENT TOOLING FOR DWPF
}

\author{
Jeff Coughlin
}

Dan Krementz

DECEMBER 2008

Savannah River National Laboratory

Savannah River Nuclear Solutions

Savannah River Site

Aiken, SC 29808 


\section{REVIEWS AND APPROVALS}

J. T. Coughlin, Co-author, Remote \& Specialty Equipment

Date

D. Krementz, Co-author, Robotics \& Remote Systems

Date

K. D. Peterson, Peer Reviewer, Robotics \& Remote Systems

Date

A. P. Fellinger, Manager, Remote \& Specialty Equipment

Date

L. T. Reid, Manager, Robotics \& Remote Systems

Date

J. R. Tihey, Manager, Waste Solidification Plant Engineering

Date

J. E. Occhipinti, Manager, Waste Solidification Engineering

Date

S. L. Marra, Manager, Robotics, Remote \& Specialty Equipment

Date

- ii - 


\section{TABLE OF CONTENTS}

LIST OF FIGURES .................................................................................................... iv

LIST OF ACRONYMS ............................................................................................... iv

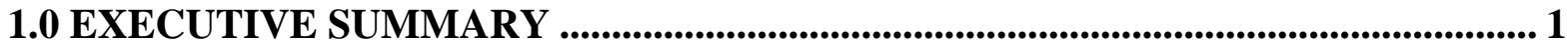

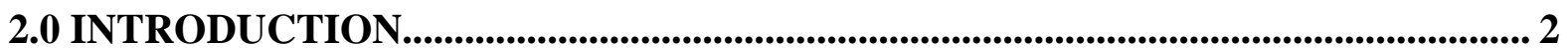

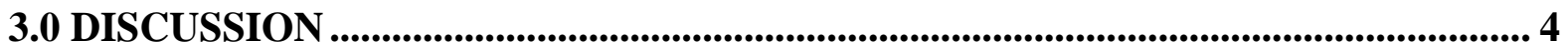

3.1 Remote Equipment Decontamination Cell (REDC) ............................................................ 4

3.2 Gasket Replacement Tooling............................................................................................... 4

3.2.1 Snap-Ring-Loading Tool ................................................................................................ 6

3.2.2 Gasket Installation Tool................................................................................. 8

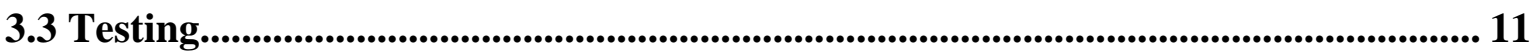

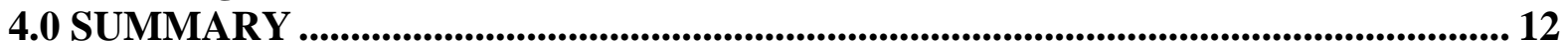

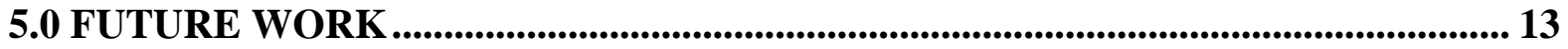

6.0 ACKNOWLEDGEMENTS ........................................................................................... 14

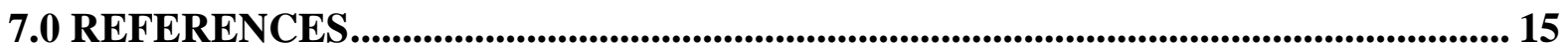

APPENDIX A. INSTALLATION TOOL FORCE CALCULATIONS........................... 16

APPENDIX B. LUBRICATION INFORMATION.................................................... 26 


\section{LIST OF FIGURES}

Figure 1: Drawing of Hanford Connector with Nozzle .......................................................... 2

Figure 2: Gasket Installation Work Table w/ Valve Station and Tools ...................................... 4

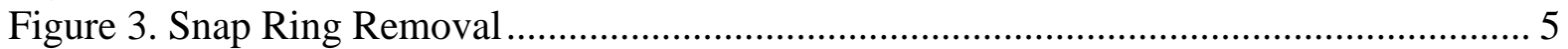

Figure 4. Snap Ring Loader Staged for Loading .................................................................... 6

Figure 5. Snap-Ring-Loading Preps ................................................................................. 7

Figure 6. Illustration of Loaded Gasket ................................................................................ 7

Figure 7. View 1 of Installation Tool in Hanford Connector (3-D Model) ................................ 8

Figure 8. View 2 of Installation Tool in Hanford Connector (3-D Model) ............................... 9

Figure 9. Installation Tool in Hanford Connector ................................................................ 10

\section{LIST OF ACRONYMS}

CDMC Contact Decontamination and Maintenance Cell

DWPF Defense Waste Processing Facility

EMM Electro-mechanical manipulator

FY fiscal year

MCU Modular Caustic Side Solvent Extraction Unit

MSM Master-slave manipulator

REDC Remote Equipment Decontamination Cell

SRNL Savannah River National Laboratory 


\subsection{EXECUTIVE SUMMARY}

The Defense Waste Processing Facility (DWPF) requested the Savannah River National Laboratory (SRNL) to develop tooling and equipment to remotely replace gaskets in mechanical Hanford connectors to reduce personnel radiation exposure as compared to the current hands-on method. It is also expected that radiation levels will continually increase with future waste streams. The equipment is operated in the Remote Equipment Decontamination Cell (REDC), which is equipped with compressed air, two master-slave manipulators (MSM's) and an electro-mechanical manipulator (EMM) arm for operation of the remote tools. The REDC does not provide access to electrical power, so the equipment must be manually or pneumatically operated. The MSM's have a load limit at full extension of ten pounds, which limited the weight of the installation tool.

In order to remotely replace Hanford connector gaskets several operations must be performed remotely, these include: removal of the spent gasket and retaining ring (retaining ring is also called snap ring), loading the new snap ring and gasket into the installation tool and installation of the new gasket into the Hanford connector. SRNL developed and tested tools that successfully perform all of the necessary tasks. Removal of snap rings from horizontal and vertical connectors is performed by separate air actuated retaining ring removal tools and is manipulated in the cell by the MSM. In order install a new gasket, the snap ring loader is used to load a new snap ring into a groove in the gasket installation tool. A new gasket is placed on the installation tool and retained by custom springs. An MSM lifts the installation tool and presses the mounted gasket against the connector block. Once the installation tool is in position, the gasket and snap ring are installed onto the connector by pneumatic actuation. All of the tools are located on a custom work table with a pneumatic valve station that directs compressed air to the desired tool and vents the tools as needed.

Extensive testing of tooling operation was performed in the DWPF manipulator repair shop. This testing allowed the operators to gain confidence before the equipment was exposed to radioactive contamination. The testing also led to multiple design improvements. On July 17 and 29, 2008 the Remote Gasket Replacement Tooling was successfully demonstrated in the REDC at the DWPF of The Savannah River Site. 


\subsection{INTRODUCTION}

The DWPF glass melter and the equipment that prepares waste for vitrification are housed inside a large enclosed facility called a "canyon". In order to perform the necessary maintenance and modifications within the canyon remotely, the canyon walls are outfitted with an array of pipe nozzles. Two nozzles within the canyon may be connected by a jumper, which is a pipe that is hung by a crane and has Hanford connectors on both ends. Each Hanford connector contains a gasket that seals to its respective canyon wall or vessel nozzle. The Hanford connector has a tapered skirt to assist the crane with placement of the connector on the nozzle and three fingers that pull against the back side of the nozzle via a remotely tightened ACME screw (Figure 1). There are both vertical and horizontal Hanford connectors, which vary only by connector orientation and the geometry of the connector skirt.

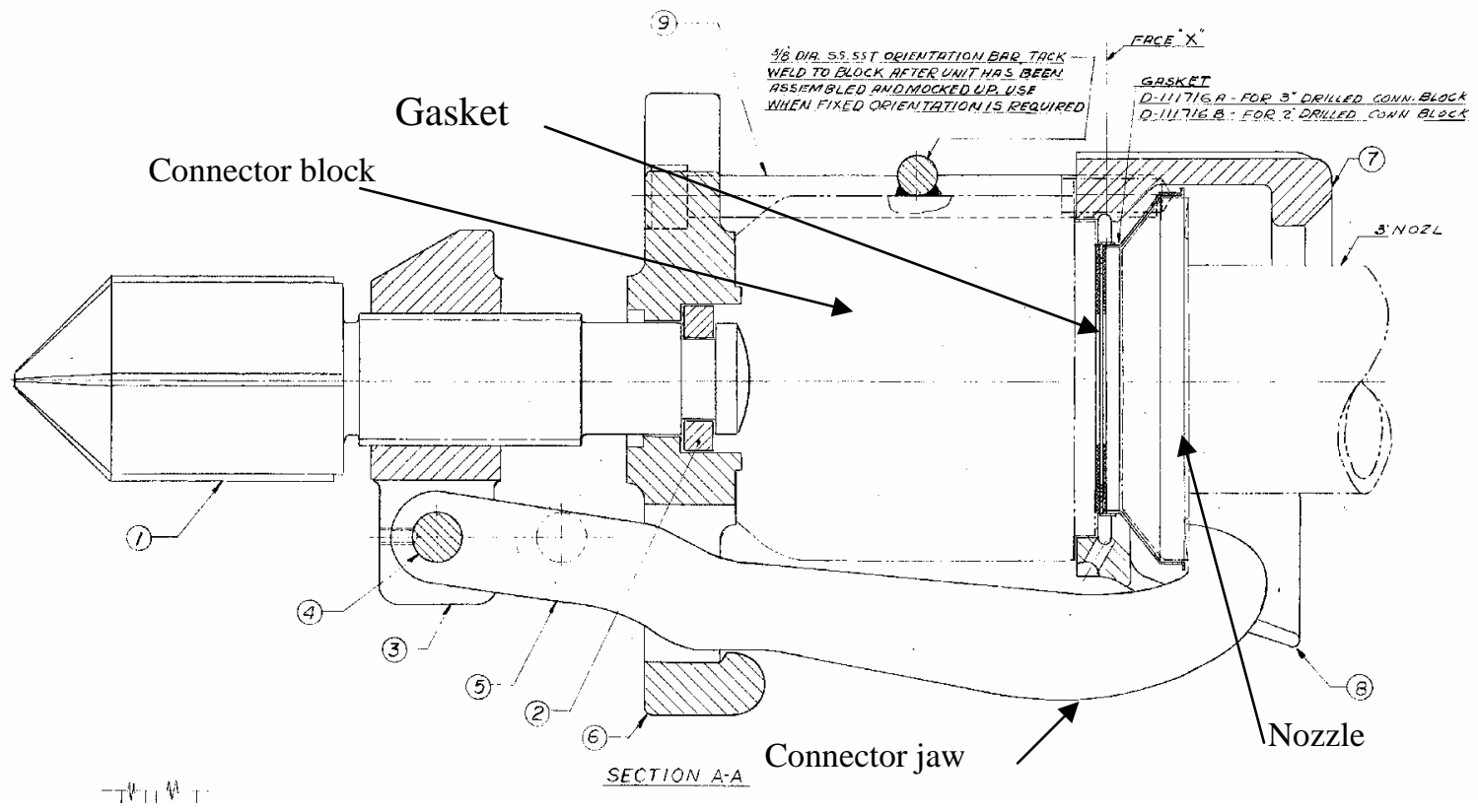

Figure 1: Drawing of Hanford Connector with Nozzle

When a Hanford connector gasket fails, the current course of action is to remove the jumper, decontaminate it as much as possible and transport the jumper to the Contact Decontamination and Maintenance Cell (CDMC) within the canyon. In this location, maintenance personnel wear protective clothing to prevent contamination and manually replace the gasket. This process requires significant planning and cost because of the risk of personnel contamination and radiation exposure.

The remote gasket replacement tooling was developed as an alternative to the hands-on gasket replacement approach. The Modular Caustic Side Solvent Extraction Unit (MCU) became operational in FY08 to process salt waste. As a result of the MCU process, an increasingly cesium-laden waste stream will be fed to DWPF over the next two years. As 
this waste enters into the DWPF system, hands-on replacement of gaskets will incur much higher personnel exposure rates than the current waste stream, thus making remote gasket replacement even more advantageous.

When the DWPF customer first requested SRNL to develop remote gasket tooling, the goal was less ambitious than it is today. Originally the task was to develop tools that would allow gasket replacement from several feet away thus eliminating hands-on contact with the jumper to reduce radiation exposure. Increasing the distance from the jumper during gasket replacement could also minimize the need for jumper decontamination prior to gasket replacement. The tools developed were designed to use a hands-on approach to load snap rings and gaskets onto an installation tool. The installation tool would then be attached to an extension arm and transported into the CDMC, where the gasket and snap ring would be installed in a Hanford connector. The goal was to develop a low cost disposable design so that decontamination between uses would not be necessary. The introduction of more highly radioactive waste to DWPF necessitated a fully remote solution. 


\subsection{DISCUSSION}

\subsection{REMOTE EQUIPMENT DECONTAMINATION CELL (REDC)}

As the name indicates, the REDC is an area of the DWPF canyon equipped for remote equipment decontamination. The cell has a large shielded window for viewing the decontamination processes. Below and in front of the window on the cell side is a 36"x72" platform for placing items to be decontaminated or in this case, gasket replacement tooling. Available for operator use are a pair of MSM's (right and left hands), an electro-mechanical manipulator (EMM), an overhead bridge crane and 100 psi compressed air supply. The MSM's are capable of handling up to $10 \mathrm{lb}$ at full reach. The EMM is capable of handling up to $100 \mathrm{lb}$. The gasket replacement work table and all associated tooling will be placed on the REDC platform during gasket replacement activities (See Figure 2).

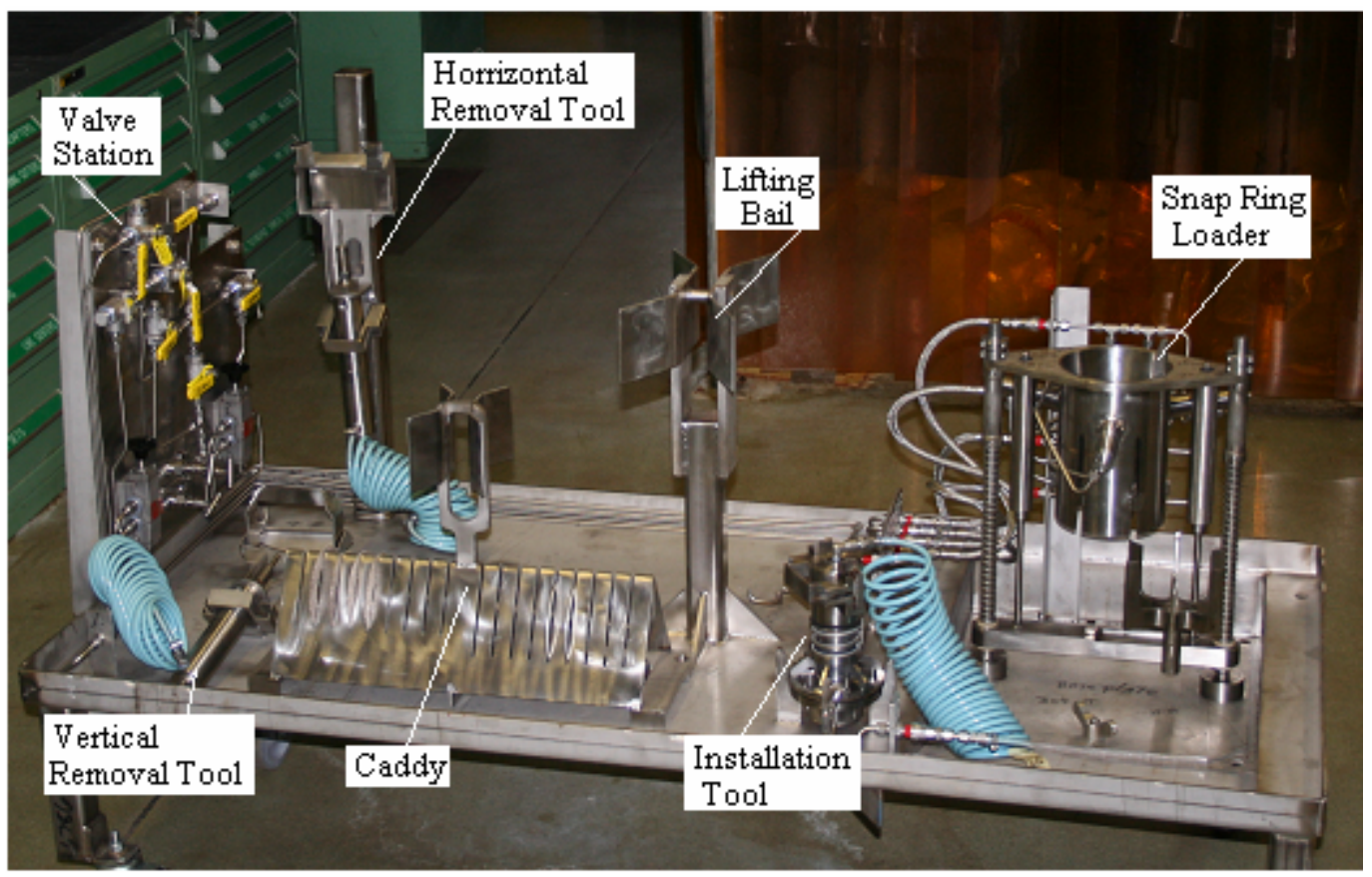

Figure 2: Gasket Installation Work Table w/ Valve Station and Tools

\subsection{GASKET REPLACEMENT TOOLING}

Several tools were developed to perform the gasket replacement task. Two snap-ringremoval tools were developed, one for the horizontal and the other for the vertical Hanford connectors. An installation tool was developed that installs both a gasket and snap ring in a vertical or horizontal Hanford connector. A snap-ring-loading tool was developed to load a snap ring into the installation tool in preparation for installation of the snap ring and gasket into the Hanford connector. The installation tool storage platform is used for gasket loading onto the installation tool. All of the tools are stored and deployed off of a stainless steel work table that has a lifting attachment that allows a crane to carry the work table in and out of the REDC as needed. On the work table is space for a removable caddy which carries 
nine gaskets and nine snap rings. The caddy is equipped with a separate lifting bail. Ideally, several caddies can be built and used to re-supply the table with new snap rings and gaskets. On the left end of the work table is a valve station that includes all of the pneumatic valves needed to run the various tools.

Before any gaskets can be replaced, the gasket replacement work table and associated tooling must be lowered onto the REDC platform by the bridge crane. The bridge crane is then used to transport the jumper into position over the work table. The EMM is used to orient the jumper so the appropriate Hanford connector is directed toward the viewing window for optimum visibility. The EMM is also used to stabilize the jumper during gasket removal and installation operations. For this task, a special EMM attachment has been designed by DWPF engineering to slide over the Acme nut of the Hanford connector.

The first operation that must be performed during remote replacement of a Hanford connector gasket is removal of the snap ring, which is used to retain the gasket against the Hanford connector block. The Hanford connector skirts on DWPF jumpers have three holes spaced $120^{\circ}$ apart that allow direct access to the snap ring. A punch can be placed in any one of the holes, which are angled such that a hammer-blow to the punch will eject the ring from its groove. These design features were utilized in development of the snap-ringremoval tools, which use an air cylinder extension to "punch" the snap ring out its groove. The only difference between the two removal tools is that one of brackets is designed to accommodate the geometry of a horizontal Hanford connector and the other that of a vertical Hanford connector.

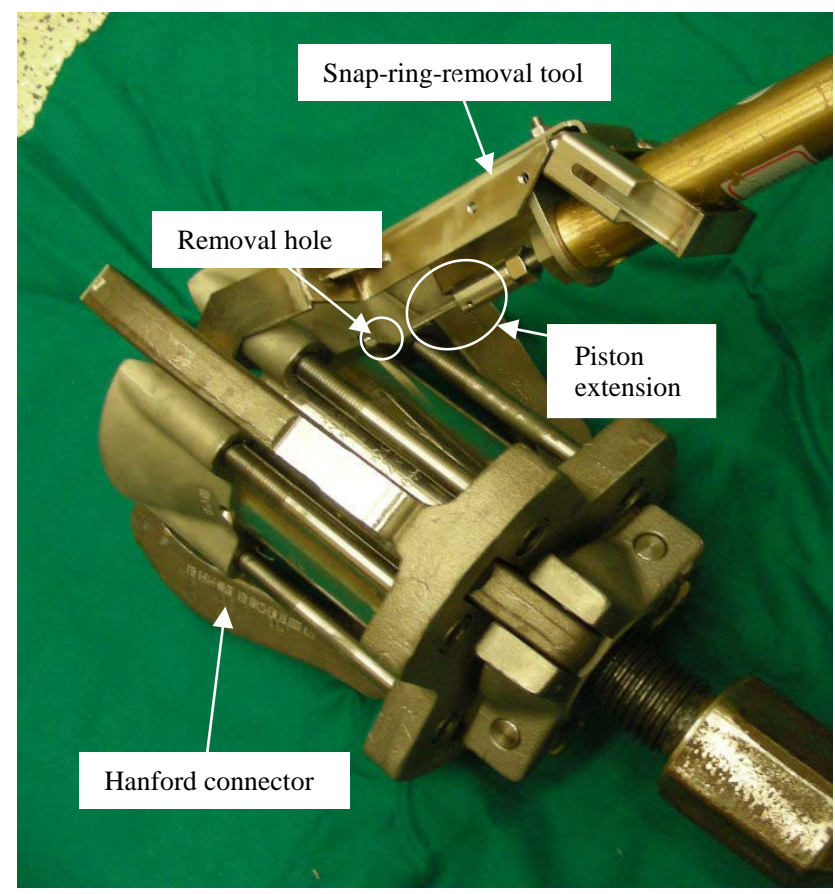

Figure 3. Snap Ring Removal

In order to use the snap-ring-removal tool, the operator must position the tool where the removal tool cylinder and bracket straddle the Hanford connector skirt and align the cylinder 
axis as well as possible with the axis of the connector hole (see Figure 3). Once the tool is in position, another operator opens a valve to supply pressurized air to the removal tool. This air pressure actuates the tool piston, forcing the pin through the connector hole and ejecting the snap ring. The cylinder is then vented so that the piston retracts. At this point, the snap ring has been removed and the gasket usually falls away from the jumper. If the gasket remains in the jumper, it is scraped off of the jumper with the MSM fingers.

\subsubsection{Snap-Ring-Loading Tool}

Before the gasket installation tool can be used, a snap ring must be "loaded" into a groove on the installation tool with geometry similar to that of a face seal o-ring groove. This is required because when the snap ring is ejected from the installation tool into the Hanford connector, the ring must already be compressed or its diameter will be too large to fit in the connector groove (see Figure 4).

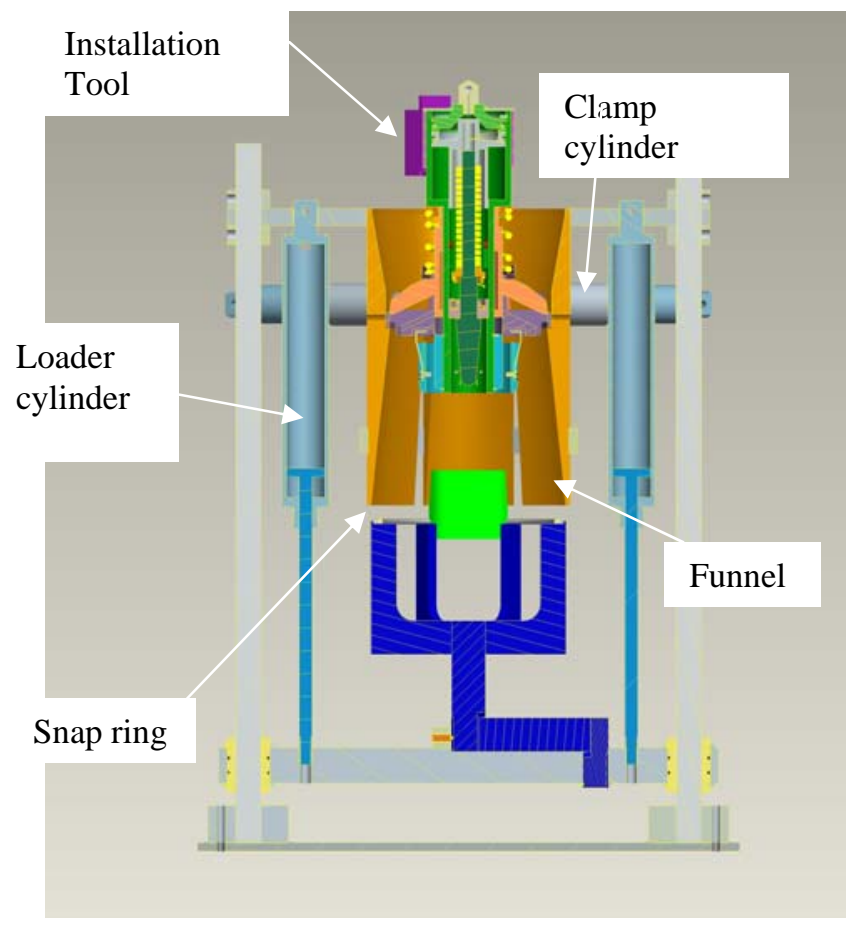

Figure 4. Snap Ring Loader Staged for Loading

The snap ring loader loads a snap ring into the installation tool by performing the following steps (see Figure 5). The manual operations are performed remotely using the REDC MSM's.

1. A snap ring is placed on the snap ring loader fingers.

2. The fingers are rotated under the loading funnel until the hard stop is hit.

3. The installation tool is placed in the funnel.

4. The clamp cylinders are actuated to lock the installation tool in position.

5. The loader cylinders are actuated to raise and compress the snap ring into the installation tool.

After the snap ring has been loaded in the installation tool, a gasket is placed on the installation tool storage mount and the installation tool is placed on top of the gasket. Six 
custom springs are mounted on the head of the installation tool to retain the gasket on the installation tool (see Figure 6).

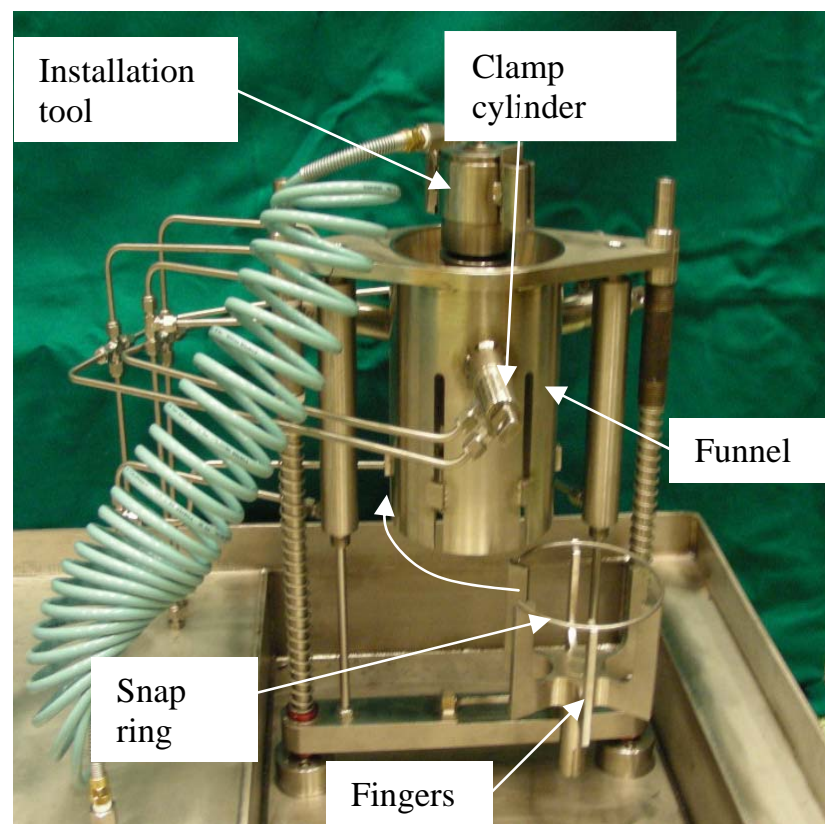

Figure 5. Snap-Ring-Loading Preps

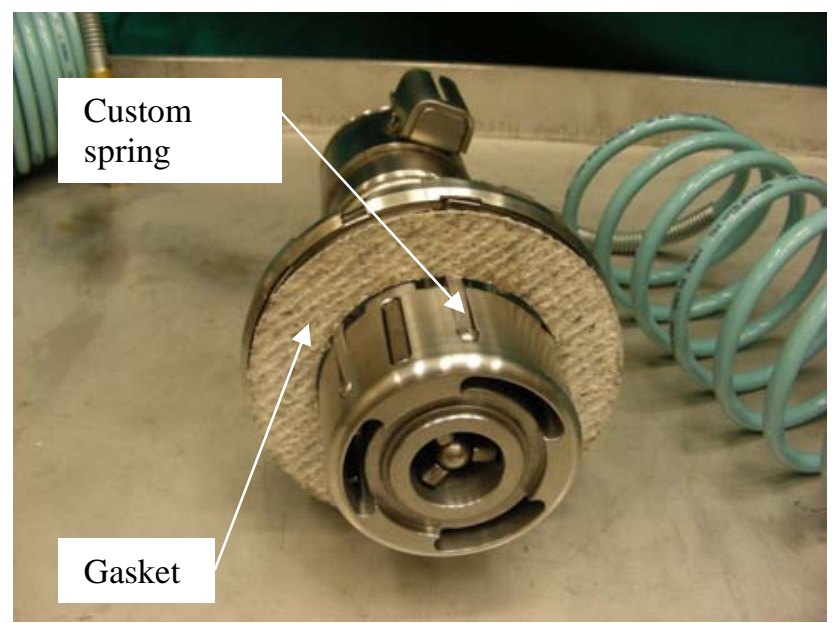

Figure 6. Illustration of Loaded Gasket 


\subsubsection{Gasket Installation Tool}

The gasket installation tool is designed to replace 3" diameter gaskets, which represent approximately $60 \%$ of the Hanford-style gaskets in service in DWPF. However, $80 \%$ of the gasket replacements during 2007 were performed on 3” Hanford connectors.

To use the gasket installation tool, an MSM operator first places the tool against the sealing face of a Hanford connector. With the tool in this position, 100 psi compressed air is provided to the tool. The air actuation causes the following sequence of actions:

1. The tool locates itself concentrically with the connector block center hole.

2. The tool anchors itself to the connector.

3. The tool advances both the gasket and the snap ring into position.

4. The snap ring expands into its groove in the connector firmly fixing the gasket.

Figure 7 shows a cross section of the installation tool inserted into a Hanford connector. In this view the tool is retracted (not pressurized). Features of interest in this view are: the MSM grips, snap ring ejector fingers, gasket, snap ring, gasket retention clips, and the Hanford connector.

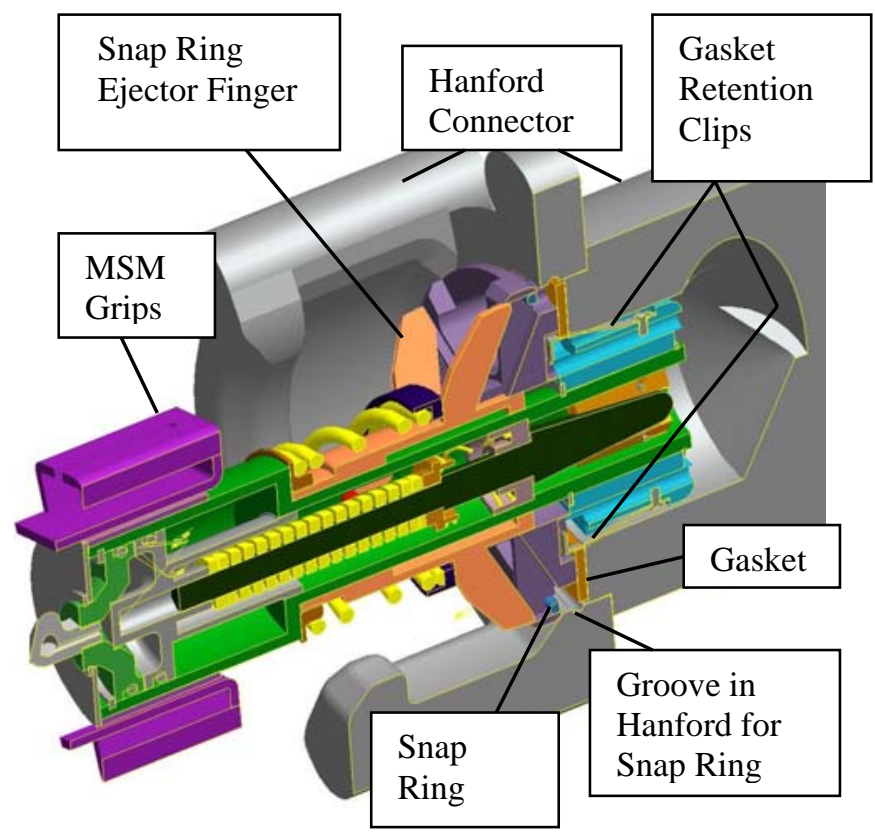

Figure 7. View 1 of Installation Tool in Hanford Connector (3-D Model)

The Hanford connector is illustrated in gray and the installation tool is shown in multi-color format. The MSM (not shown) positions the installation tool as shown against the Hanford connector via the MSM grips. When compressed air enters the tool (discussed later) the snap ring is forced forward into the Hanford connector groove by the snap ring ejector fingers. 
The gasket thickness is such that the snap ring bears against the gasket allowing it to maintain its position in the connector.

Figure 8 shows another cross-section of the installation tool. Items of interest in this figure are: dogs, wedge, pins, piston, springs and the compressed air inlet port.

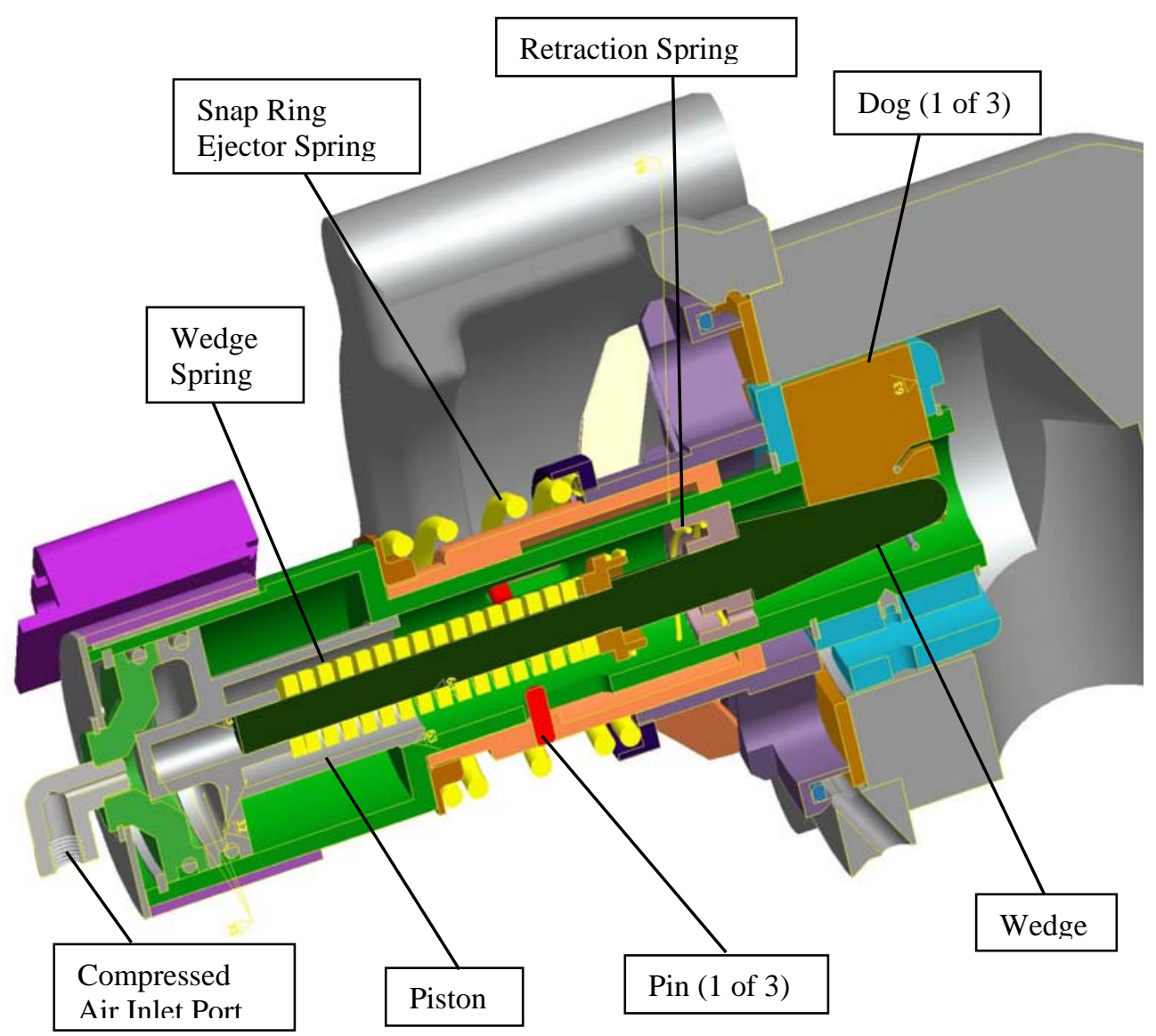

Figure 8. View 2 of Installation Tool in Hanford Connector (3-D Model)

When compressed air is introduced and builds pressure in the inlet port, the piston moves right (Figure 8) starting a sequence of tool motions. The wedge is forced right, causing the dogs to bear against the bore of the connector. After the dogs make contact with the bore no further rightward motion is possible for the wedge. Further piston stroke causes compression of the wedge spring; this adds more load on the dogs in turn increasing anchorage and alignment forces between the tool and the connector. The leading edge of the piston makes contact with three red pins. The pins are radially oriented and are part of the snap ring ejector. After contact, the pins and snap ring ejector move to the right with the piston. The snap ring ejector spring resists accidental snap ring ejection that could be caused by inadvertent motion of the snap ring ejector fingers during tool movement. The spring is compressed until the snap ring is ejected from its groove in the tool and transferred to the connector. The retraction spring is present to help retract the wedge which enhances dog retraction into the tool after the air pressure has been isolated from the tool. A garter spring 
(not annotated but fitted into a slot milled in each dog) retains each dog within the tool after removal from the connector bore.

Use of the MSM requires that the tool weight not exceed 10 lbs due to MSM load limitations. The maximum operating pressure available to the tool is limited to that existing in the facility plant air system ( 110 psig). The weight and air pressure limitations drove the custom design and a lot of the engineering optimization undertaken as part of the development of the tool.

The proportioning of the total load provided by the piston between the wedge and pins is dictated by wedge angle, spring characteristics and the extent of any preloading in the snap ring ejector spring. Examples of the analysis used to optimize features such as the wedge angle and spring selection are shown in Appendix A. The springs were chosen to proportion a large percentage of the available piston force to anchorage and alignment of the tool within the connector's hole. The geometry of the installation tool is designed to minimize the gap between the contacting surfaces of the installation tool and the connector skirt. The snap ring is radially compressed as it is loaded into the installation tool and will spring radially outward if it encounters a gap during its transit out of the installation tool to the connector. If a gap exists during installation large enough for the ring to expand open radially before reaching the snap ring groove in the connector skirt, it is expected that the installation would have to be terminated and another ring reloaded into the installation tool.

The installation tool and loading tool both have components that slide relative to each other, requiring very tight tolerances (some less than .001"). The tool must be fabricated out of stainless steel due to nitric acid exposure. Austenitic stainless is prone to gall, therefore the design called for 304 stainless components to be mated against Nitronic 60 components. The sliding surfaces are lubricated with Fel-Pro C-100 or Loctite Heavy Duty Anti-Seize. DowCorning High Vacuum silicone grease or Dow Molykote 55 silicone grease are used to lubricate the o-rings. For the threaded components, Leak Lock thread sealant by Highside Chemical is used in lieu of Teflon tape. Leak Lock is a blue paste that has no Teflon or chlorides. Appendix B provides lubrication data and supporting documentation for lubrication selection.

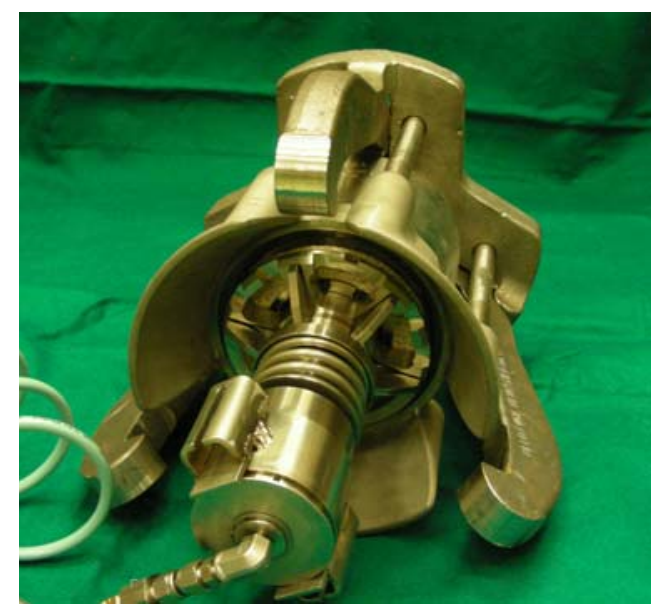

Figure 9. Installation Tool in Hanford Connector 


\subsection{TESTING}

Functional testing of the gasket replacement tooling prototypes has been performed in multiple stages. Testing of the removal tool concepts was performed using a mockup MSM in 773-50A. This initial test verified that the removal tools could eject a snap ring from a Hanford connector. Functionality of the installation tool, loading tool, removal tools and other table components were tested without an MSM in the 723-A assembly area prior to delivery to DWPF. The testing in 723-A (without an MSM) had no acceptance criteria other than verification that the equipment could perform all of the tasks required to remotely replace gaskets. Cold manipulator testing was performed in the DWPF manipulator repair shop. This testing allowed the equipment operators to comment on the function of the tools and also facilitated development of an operating procedure. Multiple changes to the tools resulted from this testing. The manipulator grips were redesigned to be closer to the center of gravity of the removal tools to reduce fatigue. The grips were also made a closed style to minimize the risk of the tool slipping from the manipulator grasp. Further testing led the grips on the horizontal tool to be flipped to enhance maneuverability. The work table was modified to incorporate quick-disconnect pneumatic fittings to allow modular replacement of the installation tool, loading tool and removal tools upon failure in the REDC. The design of the gasket and snap ring storage caddy was modified. The initial design was fixed to the table and involved stacking the gaskets and snap rings in two separate stacks. The new design stores gaskets and snap rings on a single modular caddie that has a lifting bail to allow removal and replacement with another caddy already loaded with gaskets and snap rings. This design has slots for nine gaskets and nine snap rings. The slotted design facilitates handling of the snap rings and gaskets by the MSM.

On July 17 and 29, 2008 the Remote Gasket Tool was successfully demonstrated by DWPF Operations personnel in the REDC cell using a process jumper.

A second unit of the entire system has been fabricated, functionally tested in 723-A and delivered to DWPF. The design of the second unit incorporates the design changes implemented after testing the first unit. This unit will be used for training of operations personnel to support testing of development installation tools and as a source of spare parts if needed. 


\subsection{SUMMARY}

The Hanford connector gasket replacement tooling has been successfully demonstrated using MSM's to manipulate the various tools. On July 17 and 29, 2008 the Remote Gasket Tool was successfully demonstrated in the REDC cell using a process jumper. Deployment of the existing system in the DWPF REDC for system jumper maintenance is expected during FY09. Development of installation tools for replacement of additional single hole (1-5/8”, 2") and multi-hole gaskets is planned. 


\subsection{FUTURE WORK}

DWPF has expressed interest in development of installation tools for replacement of other single hole (1-5/8”, 2”) and multi-hole gaskets. A test was performed by DWPF personnel using the existing installation tool with the bore locking feature removed to determine whether snap rings could be installed without this feature. If this is possible, design of tools for replacement of multi-hole gaskets becomes much less complex. Unfortunately, the test was unsuccessful. Lessons learned from development and testing of the 3" gasket installation tool will be applied to development of the other installation tools. 


\subsection{ACKNOWLEDGEMENTS}

The following SRS employees all played important roles in support of development, testing or deployment of the gasket replacement tooling:

\section{$\underline{\text { SRNL }}$}

George Crow

Mike Dalmaso

Garry Glazener

Bob Milling

Nick Vrettos

DWPF Engineering

Jim Gee

Brian Metzger

Randy Neuville

DWPF Operations

Rickey Jackson

Greg Lawson

Darryl Perry

Leonard Perry 


\subsection{REFERENCES}

D. Krementz, J. T. Coughlin, R. B. Milling, M. J. Dalmaso, “Development of Remote Hanford Connector Gasket Replacement Tooling for the Savannah River Site's Defense Waste Processing Facility”, $2^{\text {nd }}$ International Joint Topical Meeting on Emergency Preparedness and Response and Robotic and Remote Systems Conference Proceedings.

B. A. Metzger, J. T. Gee, D. Krementz, J. T. Coughlin, R. B. Milling, M. J. Dalmaso, "Development of Remote Hanford Connector Gasket Replacement Tooling for the Savannah River Site’s Defense Waste Processing Facility”, 2009 Waste Management Conference Abstract \#9457. 
SRNL-STI-2008-00544, REVISION 0

\section{APPENDIX A. INSTALLATION TOOL FORCE CALCULATIONS}

Problem - Determine "centering force" at location of MSM grip when pneumatic installation tool is pressurized. Examine design of tool for adequacy/optimization with respect to other operational requirements (relative to spring selection and available piston force)

Tool Operation Summary - When air pressure is introduced to the installation tool (Fig. 1), a series of events occurs sequentially as follows:

Piston is driven to the right compressing the lighter retract spring.

The wedge slides to the right as the retract spring is compressed.

As the wedge slides rightward, the dogs (total of three spaced at 120 deg around the conical-shaped wedge) are forced radially outward. This motion is required to align the axis of the installation tool with the axis of the connector block axis. If alignment is not achieved prior to the release of the snap ring out of the holder (finish of step 9 below this section), then it is likely that the spring will expand or jump out through the gap between the snap ring holder and the connector skirt (gap created due to the misalignment). If this would occur, the installation would need to be restarted by loading another snap ring into the tool.

Contact is made on the connector block hole bore which stops the retract spring compression, any further piston motion begins compressing the heavier dog spring.

The dog spring compression continues alone until the front surface of the piston makes contact with the dowel

pins.

Further piston movement is then accompanied with both the continued compression of the dog spring and movement of the snap ring ejector.

Movement of the snap ring ejector initially compresses only the installation spring until the bottom of each snap ring ejector leg bears against the left side of the snap ring (start pos.).

Further piston motion will then add one additional force, (along with the building dog spring force -- if snap ring is moving, installation spring compression should be holding steady) that of the drag of the snap ring (compressed in the snap ring holder groove $\sim 17.5 \mathrm{lbf}$ max).

Further motion should eventually cause the snap ring to be released from the holder into the skirt (this should slightly relieve the radial bearing load causing ring drag).

Further piston motion should cause the snap ring to drop into the finish position (note that due to the circular cross-sectional shape of the snap ring this will likely finish by pulling away from the ejector legs. 


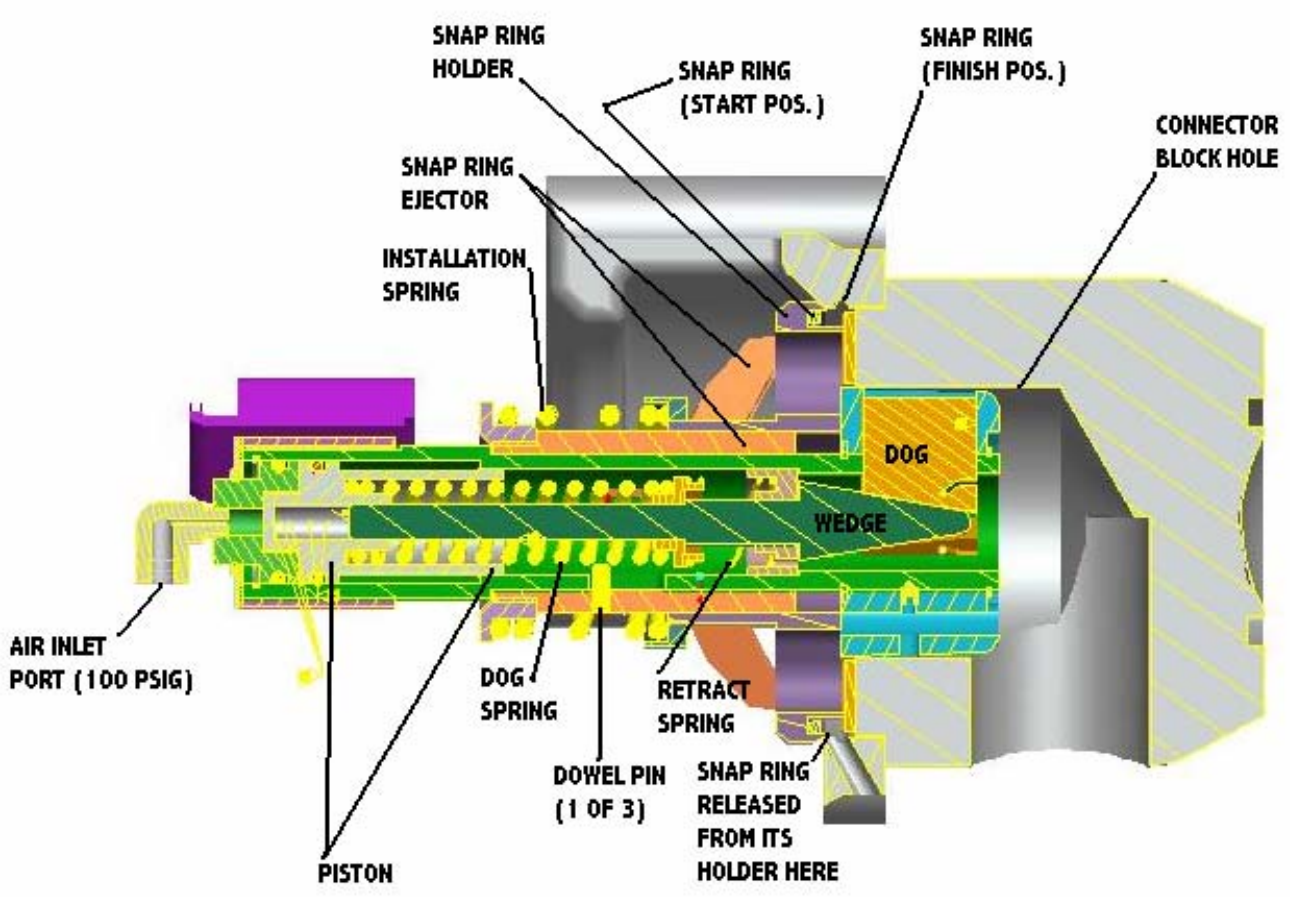

FIG A1: Pneumatic Installation Tool Cross-Section

Variable Definitions

F1=wedge force during pressurization of piston

F2=wedge force required to "pull away from dogs" when piston is depressurized

R1=reaction force of dog onto the wedge during wedge advance

$\mathrm{R} 2=$ reaction force of dog onto the wedge during wedge withdrawal

W1=wedge force on dog

$\mathrm{B}=$ bore reaction force on dog

$\mathrm{H}=$ housing reaction on dog

$\mathrm{Hf}=$ friction force between dog and housing

$\alpha=1 / 2$ of the included conical angle of the wedge or angle of "out of square cut" on dog

$\phi=$ friction angle (always measured to surface normal and directed to oppose motion)

$\mathrm{P}=$ piston load

$\mathrm{X}=$ piston travel

$\mathrm{kd}=$ spring constant of dog spring, century D-1434, 405 \#/in, Lfree=3.0, no preload

$\mathrm{kr}=$ spring constant of retract spring, century S-1256, 3.9 \#/in, Lfree $=1.31$, Lsolid=.19, preload=1.27\#

$\mathrm{ki}=$ spring constant of install spring, century S-1651, 43 \#/in, Lfree=1.94,Lsolid=.96, no preload

$\mathrm{i}=$ counter to set up a range variable to evaluate piston load at .01 in travel increments

x1min=X@ minimum tolerance connector block hole diameter, 3.009 in (Small Hole)

x1max=X @ maximum tolerance connector block hole diameter, 3.027 in (Big Hole)

x2=X @ piston contact with dowels, represents start of snap ring ejector motion (ki buildup starts)

x3=X @ start of snap ring movement, this stops ki buildup \& starts ring drag =17.5\#

$\mathrm{x} 4=\mathrm{X} @$ snap ring ejection (release) from snap ring holder, reduces ring drag to unknown. Guess=12

$\mathrm{C}=$ magnitude of couple created by misaligned dogs

$\mathrm{A}=$ aligning force measured at the center of the MSM grip 
Develop a relation/curve showing the piston loading, $P$ as a function of its travel, $X$ from start. From this relation/curve we will later determine the wedge force $F 1$.

$\begin{array}{ll}\mathrm{kd}:=405 & \mathrm{x} 1 \mathrm{~min}:=.709 \\ \mathrm{kr}:=3.9 & \mathrm{x} 1 \mathrm{max}:=.785 \\ \mathrm{ki}:=43 & \mathrm{x} 2:=.986 \\ \mathrm{i}:=0 . .151 & \mathrm{x} 3:=1.219 \\ \mathrm{X}_{\mathrm{i}}:=\frac{\mathrm{i}}{100} & \mathrm{x} 4:=1.328\end{array}$

Loop to determine piston load using the small hole case:

$$
\text { P1 : }=\left\{\begin{array}{l}
\mathrm{r} \leftarrow 0 \\
\text { for } \mathrm{i} \in 0 . .151 \\
\begin{array}{l}
\operatorname{Pr} \leftarrow 1.27+\mathrm{X}_{\mathrm{i}} \cdot \mathrm{kr} \text { if } \mathrm{X}_{\mathrm{i}}<\mathrm{x} 1 \mathrm{~min} \\
\operatorname{Pr} \leftarrow 1.27+\mathrm{x} 1 \mathrm{~min} \cdot \mathrm{kr}+\left(\mathrm{X}_{\mathrm{i}}-\mathrm{x} 1 \mathrm{~min}\right) \cdot \mathrm{kd} \text { if } \mathrm{x} 1 \mathrm{~min} \leq \mathrm{X}_{\mathrm{i}}<\mathrm{x} 2 \\
\operatorname{Pr} \leftarrow 1.27+\mathrm{x} 1 \mathrm{~min} \cdot \mathrm{kr}+\left(\mathrm{X}_{\mathrm{i}}-\mathrm{x} 1 \mathrm{~min}\right) \cdot \mathrm{kd}+\left(\mathrm{X}_{\mathrm{i}}-\mathrm{x} 2\right) \cdot \mathrm{ki} \text { if } \mathrm{x} 2 \leq \mathrm{X}_{\mathrm{i}}<\mathrm{x} 3 \\
\operatorname{Pr} \leftarrow 1.27+\mathrm{x} 1 \mathrm{~min} \cdot \mathrm{kr}+\left(\mathrm{X}_{\mathrm{i}}-\mathrm{x} 1 \mathrm{~min}\right) \cdot \mathrm{kd}+(\mathrm{x} 3-\mathrm{x} 2) \cdot \mathrm{ki}+17.5 \text { if } \mathrm{x} 3 \leq \mathrm{X}_{\mathrm{i}}<\mathrm{x} 4 \\
\operatorname{Pr} \leftarrow 1.27+\mathrm{x} 1 \mathrm{~min} \cdot \mathrm{kr}+\left(\mathrm{X}_{\mathrm{i}}-\mathrm{x} 1 \mathrm{~min}\right) \cdot \mathrm{kd}+(\mathrm{x} 3-\mathrm{x} 2) \cdot \mathrm{ki}+17.5 \text { otherwise } \\
\mathrm{r} \leftarrow \mathrm{r}+1
\end{array}
\end{array}\right.
$$

Loop to determine piston load using the large hole case:

$$
\mathrm{P} 2:=\left\{\begin{array}{l}
\mathrm{r} \leftarrow 0 \\
\text { for } \mathrm{i} \in 0 . .151 \\
\mid \begin{array}{l}
\operatorname{Pr} \leftarrow 1.27+\mathrm{X}_{\mathrm{i}} \cdot \mathrm{kr} \text { if } \mathrm{X}_{\mathrm{i}}<\mathrm{x} 1 \mathrm{max} \\
\operatorname{Pr} \leftarrow 1.27+\mathrm{x} 1 \mathrm{max} \cdot \mathrm{kr}+\left(\mathrm{X}_{\mathrm{i}}-\mathrm{x} 1 \mathrm{max}\right) \cdot \mathrm{kd} \text { if } \mathrm{x} 1 \mathrm{max} \leq \mathrm{X}_{\mathrm{i}}<\mathrm{x} 2 \\
\operatorname{Pr} \leftarrow 1.27+\mathrm{x} 1 \mathrm{max} \cdot \mathrm{kr}+\left(\mathrm{X}_{\mathrm{i}}-\mathrm{x} 1 \mathrm{max}\right) \cdot \mathrm{kd}+\left(\mathrm{X}_{\mathrm{i}}-\mathrm{x} 2\right) \cdot \mathrm{ki} \text { if } \mathrm{x} 2 \leq \mathrm{X}_{\mathrm{i}}<\mathrm{x} 3 \\
\operatorname{Pr} \leftarrow 1.27+\mathrm{x} 1 \mathrm{max} \cdot \mathrm{kr}+\left(\mathrm{X}_{\mathrm{i}}-\mathrm{x} 1 \mathrm{max}\right) \cdot \mathrm{kd}+(\mathrm{x} 3-\mathrm{x} 2) \cdot \mathrm{ki}+17.5 \text { if } \mathrm{x} 3 \leq \mathrm{X}_{\mathrm{i}}<\mathrm{x} 4 \\
\operatorname{Pr} \leftarrow 1.27+\mathrm{x} 1 \mathrm{max} \cdot \mathrm{kr}+\left(\mathrm{X}_{\mathrm{i}}-\mathrm{x} 1 \mathrm{max}\right) \cdot \mathrm{kd}+(\mathrm{x} 3-\mathrm{x} 2) \cdot \mathrm{ki}+17.5 \text { otherwise } \\
\mathrm{r} \leftarrow \mathrm{r}+1
\end{array}
\end{array}\right.
$$


Wedge force load for the small hole case:

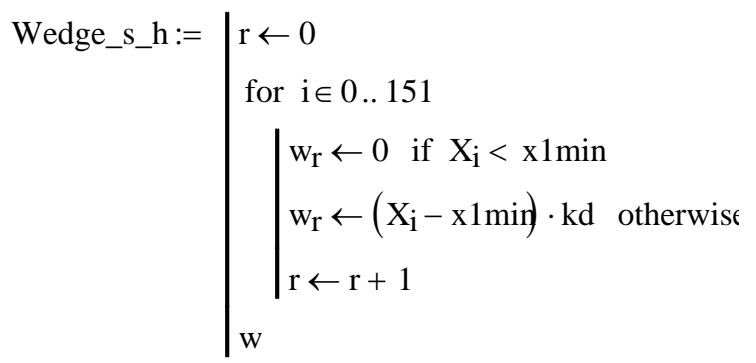

Wedge force load for the large hole case:

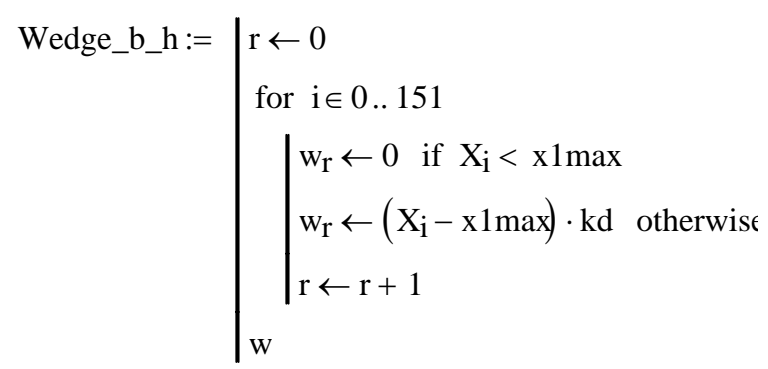


SRNL-STI-2008-00544, REVISION 0

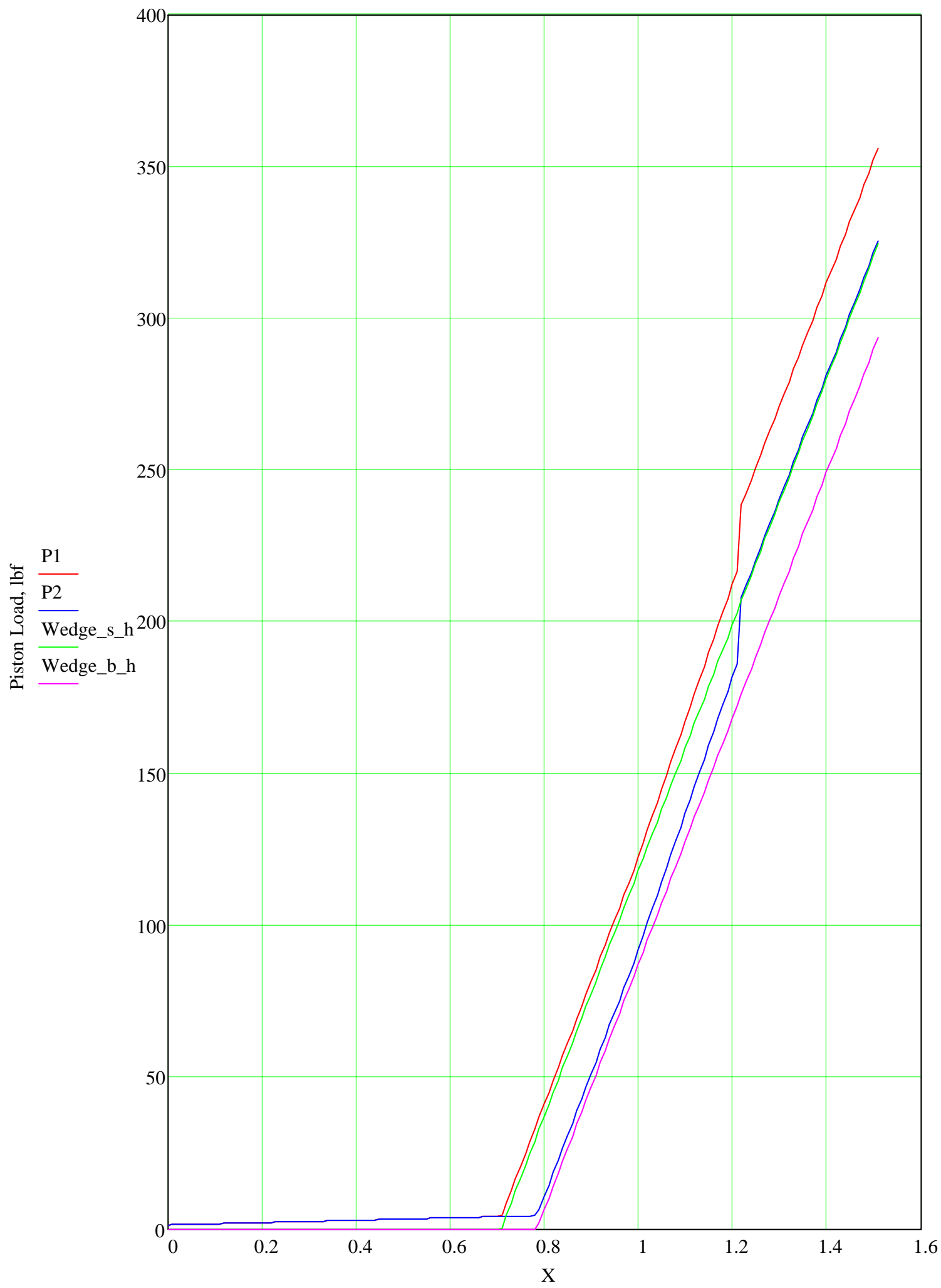

Piston Position relative to Start, in

Figure A2: Piston Load vs Piston Position 


\section{Determination of alignment force at center of MSM grip location}

To complete this part of the calculation, a relation will be developed between the wedge force applied to the dogs and the radial force applied to the connector bore by the dogs. Then another relation will be written expressing the alignment force at the MSM grip location in terms of the radial dog force couple. Friction is included in the first expression -- various values of friction will be evaluated using a range variable. The proper dog spring input force on the wedge will be determined from the earlier plot relating the piston force to the piston location. A high and low value for this force will need to also be considered as the connector hole diameter has a wide tolerance range. Final results for this section will be presented graphically.

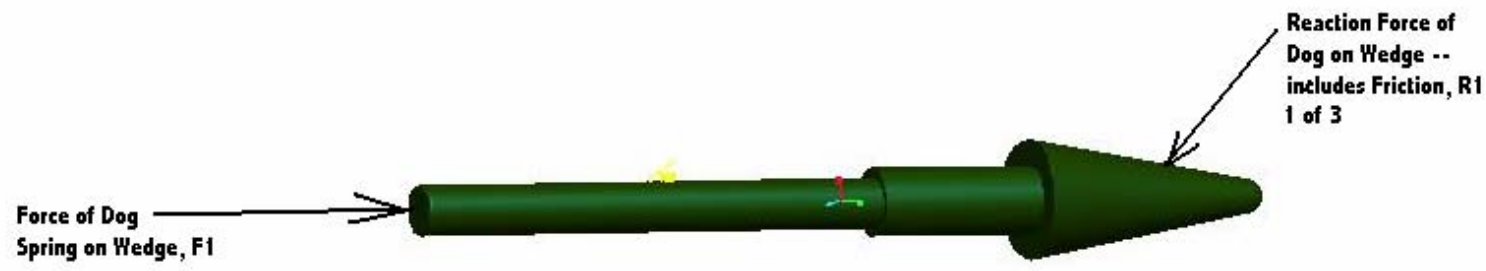

Figure A3: Orientation of Forces on Wedge during Dog Extension

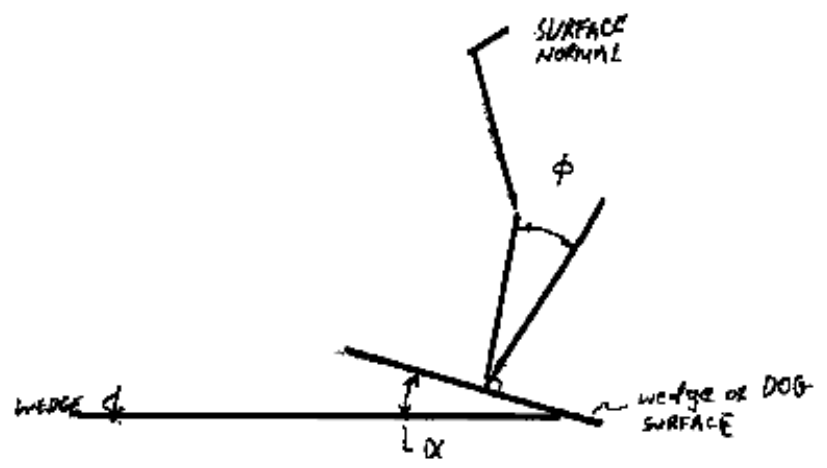

Figure A4: Generic diagram showing unlabeled force oriented at $\phi$ to the surface normal (wedge motion assumed from left to right -- illustrates how friction affects orientation of reaction w.r.t surface normal) 


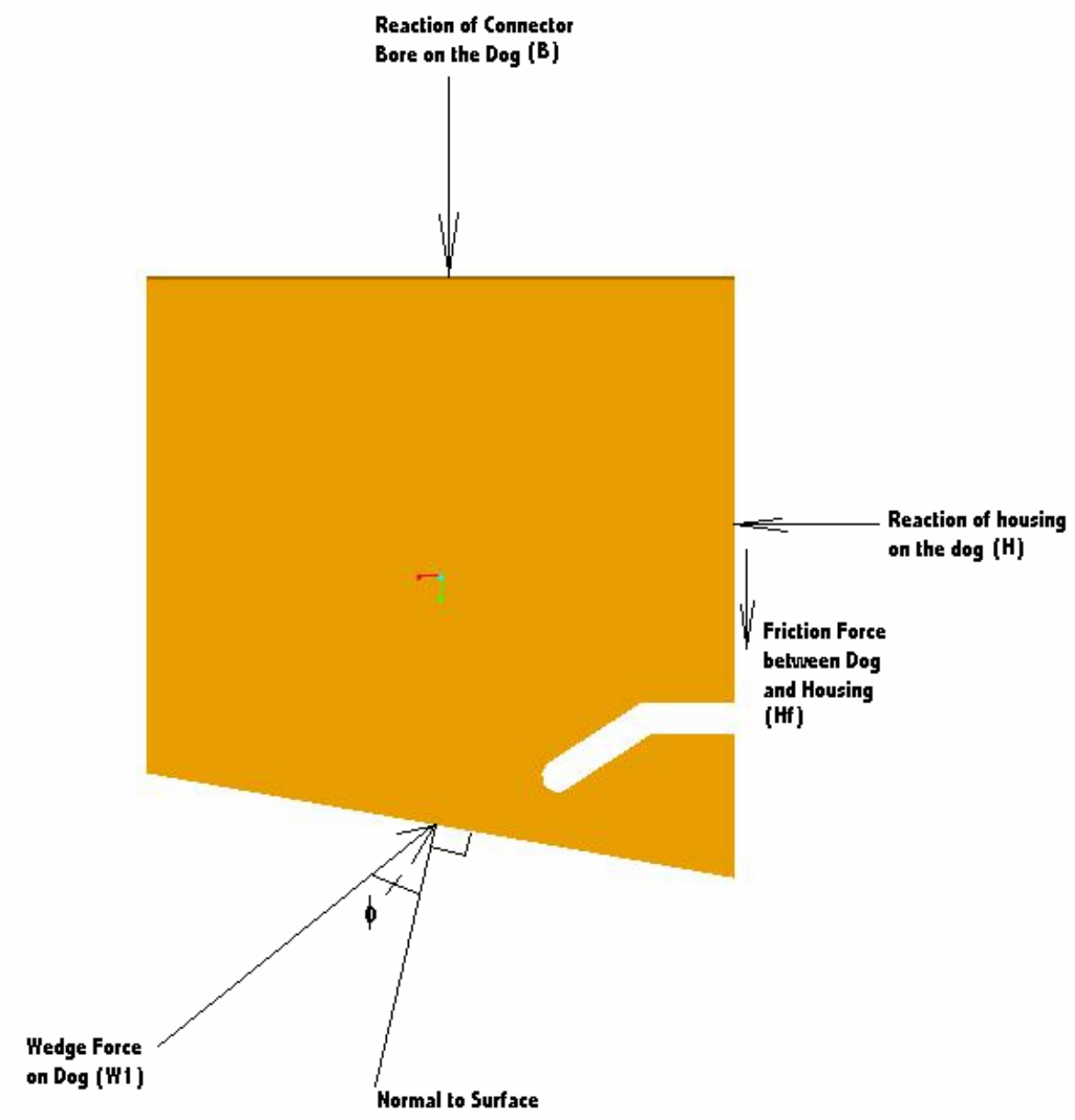

Figure A5: FBD of Dog with Equilibrium Forces Labeled

See Figures A3-A5 above for the following:

For the wedge:

From force analysis of piston vs movement from above:

Patejectminhole $=(\mathrm{x} 4-\mathrm{x} 1 \mathrm{~min}) \cdot \mathrm{kd}$

Patejectminhole $=250.695$

Patejectmaxhole: $=(\mathrm{x} 4-\mathrm{x} 1 \mathrm{max}) \cdot \mathrm{kd}$

Patejectmaxhole $=219.915$

F1s := Patejectminhol

F1b := Patejectmaxhol 
Using friction as a range variable relate wedge force to dog rxn (Fig A3 FBD of Wedge).

$$
\begin{array}{ll}
n:=0 . .70 & j:=5,6 . .10 \\
& \alpha_{j}:=j \cdot \frac{2 \cdot \pi}{360}
\end{array}
$$

$\mu_{\mathrm{n}}:=\frac{\mathrm{n}}{100}$

$\phi_{\mathrm{n}}:=\operatorname{atan}\left(\mu_{\mathrm{n}}\right)$

$R 1 s_{n, j}:=\frac{F 1 s}{3 \cdot \cos \left[\pi-\left(\frac{\pi}{2}+\phi_{n}+\alpha_{j}\right)\right]}$

$\mathrm{R}_{1} \mathrm{~b}_{\mathrm{n}, \mathrm{j}}:=\frac{\mathrm{F} 1 \mathrm{~b}}{3 \cdot \cos \left[\pi-\left(\frac{\pi}{2}+\phi_{\mathrm{n}}+\alpha_{\mathrm{j}}\right)\right]}$

From Fig A5 -- FBD of Dog

We know that the magnitude of W1=R1, using this and summation of $\mathrm{x}$-dir forces we get:

$W_{1} s_{n, j}:=R 1 s_{n, j} \quad W 1 b_{n, j}:=R 1 b_{n, j}$

$H s_{n, j}:=W 1 s_{n}, j \cdot \sin \left(\phi_{n}+\alpha_{j}\right) \quad H b_{n, j}:=W 1 b_{n}, j \cdot \sin \left(\phi_{n}+\alpha_{j}\right)$

From the friction triangle (ref. Fig 3) and apply to $\mathrm{H}$ and $\mathrm{Hf}$

$\operatorname{Hfs}_{\mathrm{n}, \mathrm{j}}:=\tan \left(\phi_{\mathrm{n}}\right) \cdot \mathrm{Hs}_{\mathrm{n}, \mathrm{j}} \quad \mathrm{Hfb}_{\mathrm{n}, \mathrm{j}}:=\tan \left(\phi_{\mathrm{n}}\right) \cdot \mathrm{Hb}_{\mathrm{n}, \mathrm{j}}$

From the summation in the y-dir and the above we get:

$B s_{n, j}:=W 1 s_{n, j} \cdot \cos \left(\phi_{n}+\alpha_{j}\right)-H f_{n, j} \quad B b_{n, j}:=W 1 b_{n, j} \cdot \cos \left(\phi_{n}+\alpha_{j}\right)-H f b_{n, j}$

If the axis of the installation tool is not lined up with the axis of the connector, then the force $\mathrm{Bs}_{n}$ will cause a couple of magnitude $=3 * 1.25 * \mathrm{Bs}_{\mathrm{n}}$

$\mathrm{Cs}_{n, j}:=1.25 \cdot \mathrm{Bs}_{n, \mathrm{j}} \quad \mathrm{Cb}_{n, j}:=1.25 \cdot \mathrm{Bb}_{\mathrm{n}, \mathrm{j}}$

The distance from the center of this couple to the center of the MSM grip is approximately $6.7 \mathrm{in}$. Therefore the aligning force measured at the MSM grip center is:

$$
\mathrm{As}_{\mathrm{n}, \mathrm{j}}:=\frac{\mathrm{Cs}_{\mathrm{n}, \mathrm{j}}}{6.7} \quad \mathrm{Ab}_{\mathrm{n}, \mathrm{j}}:=\frac{\mathrm{Cb}, \mathrm{j}}{6.7}
$$




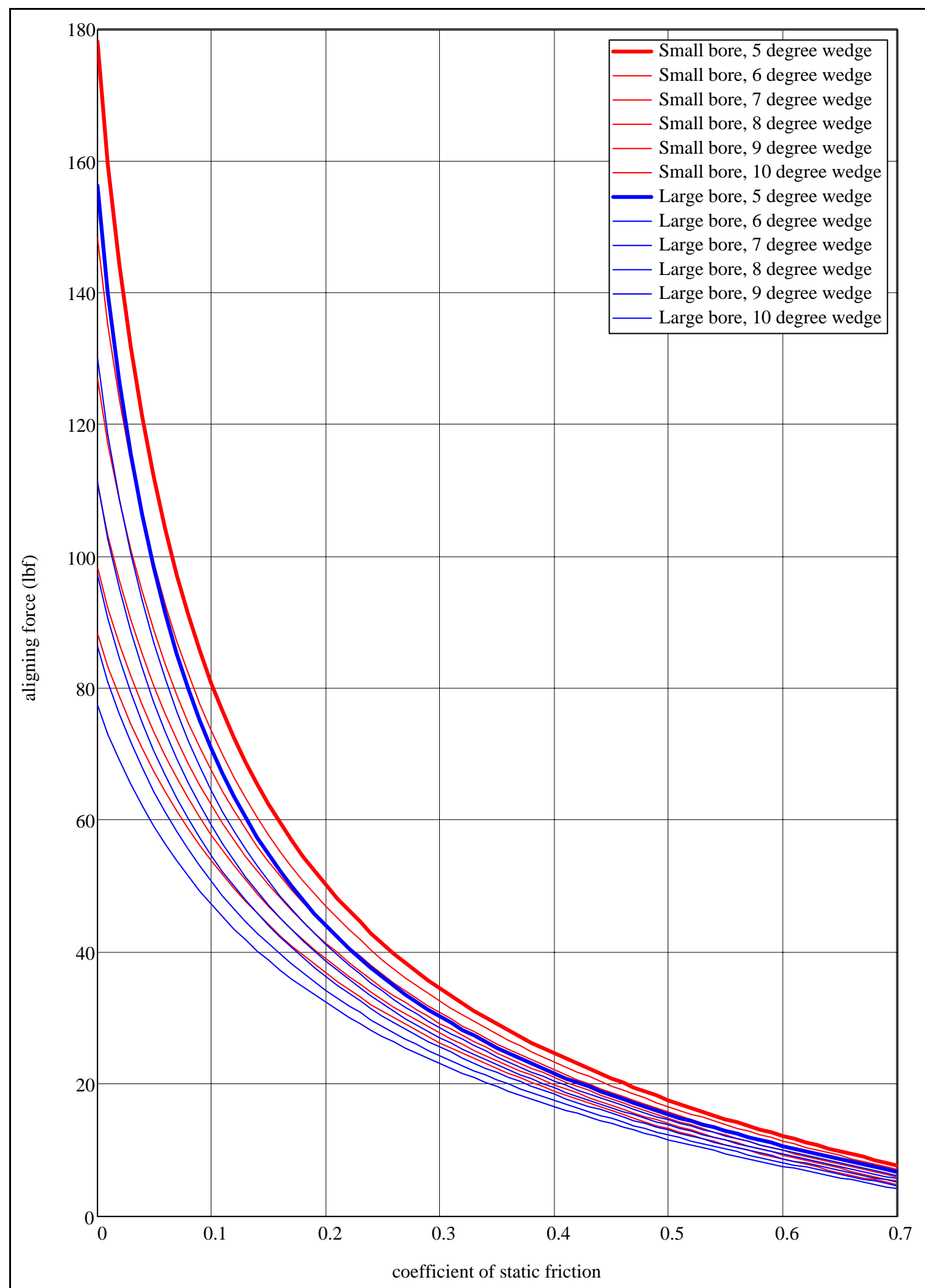

Figure A6: Effect of friction coefficient on aligning force 


\section{Conclusions}

The family of curves in Figure A6 shows the effect of the coefficient of friction on the aligning force. The effect of variations in the wedge angle is also seen. Any variation away from the current design value of 5 deg. would have to be reviewed to see if the tool would operate properly. It could be easy to erroneously assume that increasing the actuation pressure above 100 psig would increase the alignment force. Per this calculation, a higher pressure would not change the alignment force since the dog spring would still be compressed the same amount at the snap ring ejection. On the other hand, it is possible that increasing the actuation pressure could momentarily increase the alignment force if the blind hole in the piston acts as an air spring as the wedge slides down in the piston. This is not easy to realistically quantify and has been ignored in this calculation. The dog spring cannot be preloaded since it would prevent the wedge from retracting when the air pressure is removed. A potential way to improve the alignment force is to select a new dog spring. Note that a stiffer dog spring would probably require a larger piston or higher pressure.

Fel-Pro C-100 anti-seize was used to lubricate the stainless-on-stainless mating surfaces. Per Fel-Pro and Loctite literature (see Appendix B), the torque coefficient of Fel-Pro C-100 is .19 and the friction coefficient is 2/3 of the torque coefficient, which in the application makes the friction coefficient .127. Given this friction coefficient, Figure A6 indicates that the aligning force will be between 60-70 lbf depending on actual bore diameter.

Figure A2 indicates that the maximum piston load $(\mathrm{P} 1 \mathrm{max})=356 \mathrm{lbf}$.

A piston diameter of 2.141" @ 100 psig thus provides enough force to overcome the piston load. $\phi 2.1875$ would give an extra $20 \mathrm{lbf}$ if needed for internal binding or friction. The piston ID was thus designed at 2.1875" to provide this margin. Any additional increase of the piston ID makes the resulting spacing between MSM grips greater than the MSM's grip range. 


\section{APPENDIX B. LUBRICATION INFORMATION}

TO: S. W. Wilkerson, 704-S

G. E. Lawson, 210-S

A. H. Welch, 210-S

FROM: $\quad$ M. S. Miller, 704-S

J. T. Gee, 704-25S

SUBJECT: Engineering Position: Aćceptable Thread Lubricant for Mechanical Fasteners (U)

\section{Background}

There is some confusion over the proper thread lubricant for mechanical fasteners to be used with the DWPF Piping Specifications (T-ESR-S-00010). Many of the DWPF Piping Specifications suggest the use of "graphite oil thread lubricant. Engineering Guide No.15060 suggests the use of a lubricant similar to "Fel-Pro C-100 Antiseize Compound" for fasteners. This product has been replaced with a lead free version of C-100 (i.e., C-102) called "Heavy Duty Anti-Seize Compound." The product is based on graphite/calcium fluoride. Discussions with key personnel from within DWPF have suggested that a LOCTITE, copper based product, called "C5-A" had been used as fastener lubricant. The use of this product did not follow either the DWPF Piping Specification or the site Engineering Guide 15060.

\section{Objective}

This Engineering Position will provide a list of acceptable fastener lubricants that can be used in DWPF piping systems. The intent of the document will be to expand the list of acceptable lubricant choices and, if necessary, set limits where these products cannot be used. While specific products will be listed in this document, other similar products may be acceptable after engineering review and approval.

\section{Discussion}

WSE has reviewed documentation on several different types of anti-seize lubricants for threaded fasteners. Products reviewed included compounds based on nickel/graphite, copper copper/graphite, and graphite-oil. Several products are available as "nuclear grade" which will ensure low halide content for stainless steel service. Product literature clearly states that copper based thread lubricants should not be used in concentrated acid service (i.e., nitric acid, etc.). All of these products appear to be acceptable as anti-seize compounds, although some are limited in highly oxidizing environments.

An effort was made to determine the basis for the "graphite-oil thread lubricant" criteria in many of the DWPF Piping Specifications. Some of the original DuPont P-codes specified "graphite/oil" fastener lubricant. Tyler French of the Piping and Valves Committee was not aware of the original basis, but stated that in his opinion any commercial anti-seize compound would be acceptable.

The Wrac Taam: Washington Savannah River Company LC • Bechtel Savannah River, Inc. • BNG America Savenneh River Corporation • BWXT Savannah River Company • CH2 Sevannah River Company 
LWO-WSE-2006-00001

Page 2 of 3

The list of possible fastener lubricants was also reviewed with Eric Skidmore and Charlie Jenkins of the Materials Technology Section (SRNL). They concurred that any of the commercial anti-seize compounds would be acceptable for most services. For nitric acid service, they agreed that copper based anti-seize compounds (e.g., C5-A) were not compatible. Even in this case, however, the joint would have to leak for the nitric acid to attack the thread lubricant. At worst, this may lead to seizing between the fastener components. It was noted that nuclear grade anti-seize compounds were available that should meet all our fastener lubricant needs. Such products would be available at premium prices, however. The consensus opinion was that selection of fastener lubricant should be based on cost and availability, providing special needs are met (e.g., halide content on stainless steels, nitric acid service, etc.).

\section{Engineering Position}

Engineering approves the use, with limitations noted, of the following commercial anti-seize compounds for fasteners contained within DWPF piping systems. Fastener lubricants specified within DWPF Piping Specifications will be considered guidance only and will not limit the choices outlined in this memorandum.

1. . Graphite-Oil Thread Lubricant (generic)

2. Graphite/Calcium Fluoride Based Products
a. LOCTITE'"Fel-Pro C-100 Anti-Seize Compound"

b. LOCTITE "Heavy Duty Anti-Seize"

i. C-102 (lead free C-100 replacement)

3. Nickel/Graphite Based Products

a. NEVER-SEEZ "Nickel Special, Nuclear Grade

4. Nickel/Graphite in Petroleum Carrier Based Products

5. a. LOCTITE "N-5000"(low halide content, suitable for stainless steel)

5. Calcium Oxide/Graphite Based Products

6. Copper Based Products
a. LOCTITE "N-7000" (low halide content, suitable for stainless steel)

a. LOCTITE "C5-A"

7. Copper/Graphite with Petroleum Carrier Based Products

a. LOCTITE "N-1000"

General Restrictions on Anti-Seize Compounds:

1. Copper based lubricants should not be used for piping containing nitric acid.

2. Stainless steel piping systems that are expected to experience temperatures in excess of $104^{\circ} \mathrm{F}$ should use low chloride anti-seize compounds (i.e., Nuclear Grade).

'NOTE: DWPF has a large quantity (three 1-gal. cans) of "Pure Nickel Special, Nuclear Grade" (Material ID: 714S-5353) of surplus lubricant that was purchased for an earlier gasket study. This is considered acceptable for all DWPF piping service. 
SRNL-STI-2008-00544, REVISION 0

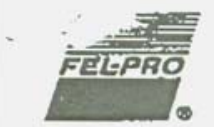

FOR REFERENCE ONLY.

CDPY

C-100 vs HEAVY DUTY ANTI-SEIZE (formerly C-102)

TECHNICAL COMPARISONS

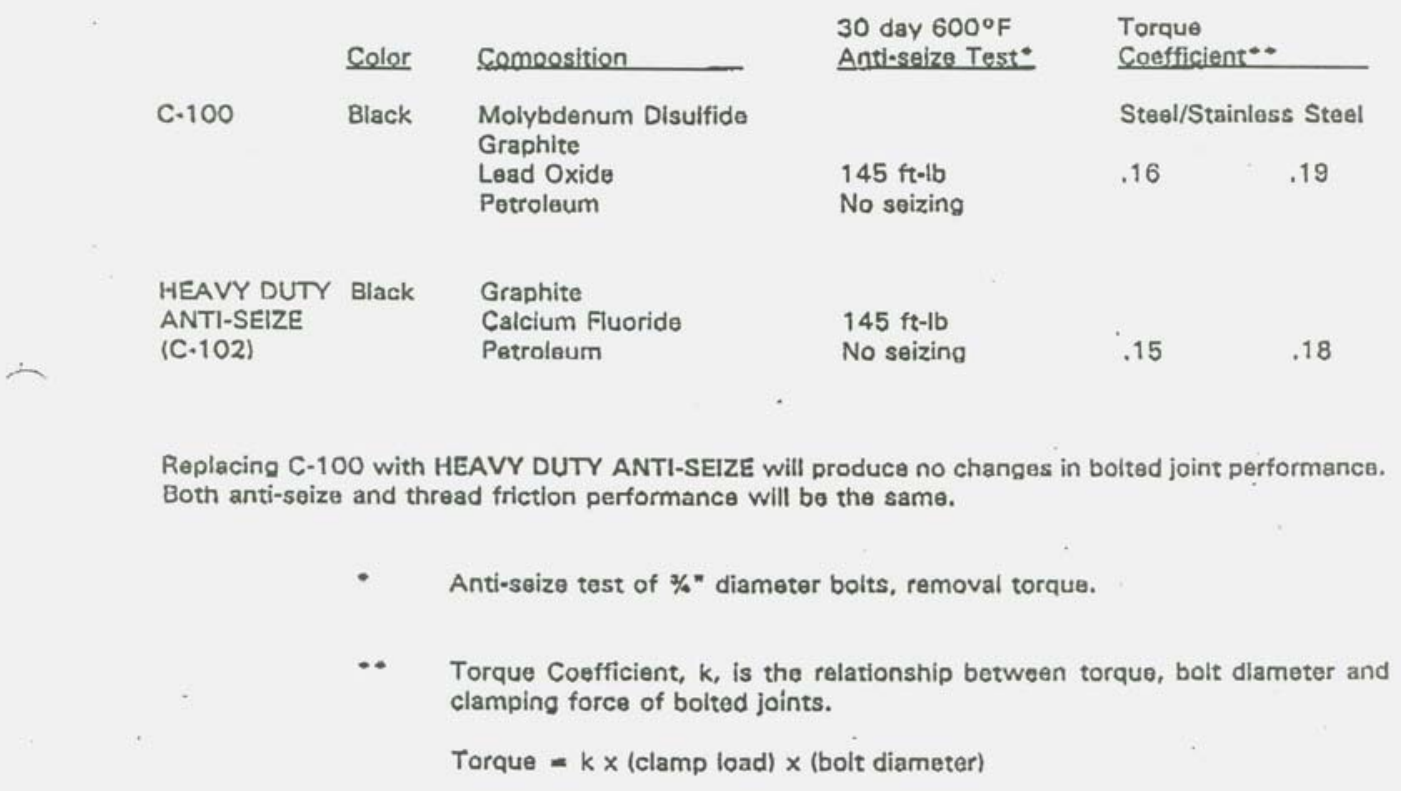


SRNL-STI-2008-00544, REVISION 0

Torque Guide

Proper clamp

load is an

essential part

of any bolted

assembly for

trouble-free

operations.

Torquing either

nut or bolt creates the clamp load.

An anti-seize lubricant used on a bolt

helps to develop greater clamp load

for the same torque compared to an

unlubricated bolt. An additional

benefit is greater uniformity in

clamp load among a series of bolts.

The relationship between torque and

clamp load is expressed in the

following equation: $\mathrm{T}$ = KFD

\section{Where:}

$\mathrm{T}=$ Torque (in.,-lb, ft, $-1 \mathrm{~b}, \mathrm{~N}-\mathrm{m})$

$\mathrm{F}=\operatorname{Clamp} \operatorname{Load}(\mathrm{lb}, \mathrm{N})$

$\mathrm{D}=$ Nominal diameter of bolt (in., ft., m)

$\mathrm{K}=$ Torque coefficient or nut factor, determined experimentally

K Factors: $K$ factors are obtained on Grade $8,1 / 2$ " steel bolts and grade 5 nuts by a test procedure that measures torque tension properties Lubricant was applied to the bolt threads and both faces of the washer.

See the Properties Chart for the

torque coefficient or $\mathrm{K}$ value for the anti-seize compounds

Henkel Corporation believes that

this data fairly represents

performance to be expected. However, Henkel makes no warranty of specific performance on any individual fastener. In critical applications, it is necessary to determine $\mathrm{K}$ values independently,

Note: There are two "coefficients" used to express the relationstip between torque and tension: torque coefficient (also called "mut factor") is the most commonly used. A different concept is the "friction coefficient," which has value $2 / 3$ (or $67 \%$ ) of the torgue coefficient.

\section{Loctite $^{\varpi}$ Anti-Seize Properties Chart}

\begin{tabular}{|c|c|c|c|c|c|c|}
\hline \multicolumn{2}{|c|}{ PRODUET } & $\begin{array}{l}\text { Item } \\
\text { Number }\end{array}$ & $\begin{array}{l}\text { Package } \\
\text { Type \& Size }\end{array}$ & \begin{tabular}{|l} 
TEMPERATURE \\
RESISTANCE
\end{tabular} & COLOR & $\begin{array}{c}K- \\
\text { YALE }\end{array}$ \\
\hline \multirow{5}{*}{ 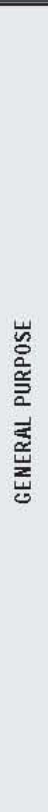 } & $\begin{array}{l}\text { C5- } \AA^{\odot} \text { Copper } \\
\text { Anti-Seize Lubricant }\end{array}$ & $\begin{array}{l}51299 \\
51277 \\
51001 \\
51002 \\
51144 \\
51147 \\
51005 \\
51003 \\
51004 \\
51006 \\
51007 \\
39643 \\
51008 \\
51009 \\
38584 \\
51011 \\
51146 \\
\end{array}$ & $\begin{array}{l}2 \mathrm{~g} \text { pouch } \\
7 \mathrm{~g} \text { pouch } \\
1 \mathrm{oz} \text {. ube } \\
4 \mathrm{oz} \text {. ube } \\
4 \mathrm{oz} \text {. brush-top can } \\
8 \mathrm{oz} \text {. brush-top can } \\
10 \mathrm{oz} \text {. brush-top can } \\
12 \mathrm{oz} \text {. net vtt. aerosol } \\
13 \text { oz.cartridge } \\
1 \text { b. can } \\
1 \text { b.brush-top can } \\
1 \text { b.brush-top metal can } \\
2.5 \text { b.can } \\
8 \text { b.can } \\
25 \text { b. pail } \\
42 \text { b. pail } \\
425 \text { b.drum }\end{array}$ & \multirow[t]{2}{*}{$\begin{array}{l}1800^{\circ} \mathrm{F} \\
\left(962^{\circ} \mathrm{C}\right)\end{array}$} & \multirow[t]{2}{*}{ Copper } & \multirow[t]{2}{*}{0.16} \\
\hline & $\begin{array}{l}\text { QuickStix"' C5-A } \\
\text { Copper Anti-Seize }\end{array}$ & $\begin{array}{l}37229 \\
39222\end{array}$ & $\begin{array}{l}20 \text { g stick } \\
40 \text { g stick }\end{array}$ & & & \\
\hline & $\begin{array}{l}\text { Sihrer Grade } \\
\text { Anti-Seize }\end{array}$ & $\begin{array}{l}38181 \\
80209 \\
76732 \\
76759 \\
76764 \\
80206 \\
76775 \\
\end{array}$ & $\begin{array}{l}7 \mathrm{~g} \text { pouch } \\
4 \text { oz. brush-top can } \\
8 \text { oz. brush-top can } \\
12 \text { oz. net wt. aerosol } \\
1 \text { lb. brush-top can } \\
1 \text { gallon can } \\
5 \text { gallon pail }\end{array}$ & \multirow[t]{2}{*}{$\begin{array}{l}1600^{\circ} \mathrm{F} \\
\left(871^{\circ} \mathrm{C}\right)\end{array}$} & \multirow[t]{2}{*}{ Silver } & \multirow[t]{2}{*}{0.18} \\
\hline & $\begin{array}{l}\text { QuickStix"' Silhrer } \\
\text { Grade Anti-Seize }\end{array}$ & $\begin{array}{l}37230 \\
39223\end{array}$ & $\begin{array}{l}20 \mathrm{~g} \text { stick } \\
40 \mathrm{~g} \text { stick }\end{array}$ & & & \\
\hline & Nickel Anti-Seize & $\begin{array}{l}77124 \\
51286 \\
51102 \\
77164 \\
51152 \\
77175\end{array}$ & $\begin{array}{l}8 \text { oz. brush-top can } \\
12 \text { oz. net wt. aerosol } \\
1 \text { l b. can } \\
1 \text { lb. brush-top can } \\
8 \text { b. can } \\
5 \text { gal. pail }\end{array}$ & $\begin{array}{c}2400^{\circ} \mathrm{F} \\
\left(1315^{\circ} \mathrm{C}\right)\end{array}$ & Silver & 0.13 \\
\hline \multirow{4}{*}{ 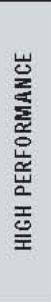 } & $\begin{array}{l}\text { Heavy Duty } \\
\text { Anti-Seize }\end{array}$ & $\begin{array}{l}51609 \\
51605 \\
51606 \\
51607 \\
51608\end{array}$ & $\begin{array}{l}10 z \text {. ube } \\
9 \text { oz. brush-top can } \\
12 \text { b. brush-top can } \\
2.3 \text { b. can } \\
45 \text { b. pail }\end{array}$ & $\begin{array}{l}2400^{\circ} \mathrm{F} \\
\left(1315^{\circ} \mathrm{C}\right)\end{array}$ & Black & 0.16 \\
\hline & $\begin{array}{l}\text { QuickStix"' Heary } \\
\text { Duty Anti-Seize }\end{array}$ & 41205 & $20 \mathrm{~g}$ stick & $\begin{array}{l}2400^{\circ} \mathrm{F} \\
\left(1315^{\circ} \mathrm{C}\right)\end{array}$ & Black & 0.16 \\
\hline & $\begin{array}{l}\text { Marine Grade } \\
\text { Anti-Seize }\end{array}$ & $\begin{array}{l}34395 \\
34026\end{array}$ & $\begin{array}{l}8 \text { oz. brush-top can } \\
16 \text { oz. brush-top can }\end{array}$ & $\begin{array}{l}2400^{\circ} \mathrm{F} \\
\left(1315^{\circ} \mathrm{C}\right)\end{array}$ & Black & 0.18 \\
\hline & $\begin{array}{l}\text { White Hi-Temp } \\
\text { Anti-Seize }\end{array}$ & $\begin{array}{l}34517 \\
34518\end{array}$ & $\begin{array}{l}80 \text { oz. brush-top can } \\
16 \text { oz. brush-top can }\end{array}$ & $\begin{array}{l}2000^{\circ} \mathrm{F} \\
\left(1093^{\circ} \mathrm{C}\right)\end{array}$ & White & 0.16 \\
\hline \multirow{5}{*}{ 咅 } & $\begin{array}{l}\text { Food Grade } \\
\text { Anti-Seize }\end{array}$ & $\begin{array}{l}51168 \\
51170 \\
51171 \\
\end{array}$ & $\begin{array}{l}80 \text { oz. brush-top can } \\
2 \text { b. can } \\
40 \text { b. pail } \\
\end{array}$ & $\begin{array}{c}750^{\circ} \mathrm{F} \\
\left(400^{\circ} \mathrm{C}\right)\end{array}$ & White & 0.13 \\
\hline & Graphite-50"' Anti-Seize & 51084 & $1 \mathrm{lb}$. can & $900^{\circ} \mathrm{F}\left(482^{\circ} \mathrm{C}\right)$ & Black & 0.13 \\
\hline & Moly Paste & $\begin{array}{l}51050 \\
51048 \\
51049 \\
51145 \\
\end{array}$ & \begin{tabular}{|l|}
12 oz. net vut. aerosol \\
8 oz. brush-top can \\
1 b. brush-top can \\
15 b. can \\
\end{tabular} & $\begin{array}{l}750^{\circ} \mathrm{F} \\
\left(400^{\circ} \mathrm{C}\right)\end{array}$ & Black & 0.11 \\
\hline & Moly-50"' Anti-Seize & 51094 & $1 \mathrm{lb}$.can & $750^{\circ} \mathrm{F}\left(400^{\circ} \mathrm{C}\right)$ & Black & 0.13 \\
\hline & Zinc Anti-Seize & 39901 & $1 \mathrm{lb} \cdot \mathrm{can}$ & $750^{\circ} \mathrm{F}\left(400^{\circ} \mathrm{C}\right)$ & Grey & 0.15 \\
\hline \multirow{4}{*}{$\begin{array}{l}\text { ᄅ } \\
\text { 言 } \\
\text { 寍 } \\
\text { 至 }\end{array}$} & $\begin{array}{l}\text { N-7000' High Purity } \\
\text { Anti-Seize }\end{array}$ & $\begin{array}{l}51272 \\
51270 \\
51273\end{array}$ & $\begin{array}{l}8 \text { oz. brush-top can } \\
1 \text { b. brush-top can } \\
2 \text { b. can }\end{array}$ & $\begin{array}{l}2400^{\circ} \mathrm{F} \\
\left(1315^{\circ} \mathrm{C}\right)\end{array}$ & Silver & 0.16 \\
\hline & $\begin{array}{l}\text { N-5000"' High Purity } \\
\text { Anti-Seize }\end{array}$ & $\begin{array}{l}51346 \\
51243 \\
51269 \\
51246 \\
51245\end{array}$ & $\begin{array}{l}1 \text { oz. tube } \\
8 \text { oz. brush-top can } \\
11 \text { lb. brush-top can } \\
2 \text { lb. can } \\
8 \text { lb. can }\end{array}$ & $\begin{array}{l}2400^{\circ} \mathrm{F} \\
\left(1315^{\circ} \mathrm{C}\right)\end{array}$ & Silwer & 0.15 \\
\hline & $\begin{array}{l}\text { High Performance } \\
\text { N-5000"' High Purity } \\
\text { Anti-Seize }\end{array}$ & 51572 & $1 \mathrm{ll}$. brush-top can & $\begin{array}{c}2400^{\circ} \mathrm{F} \\
\left(1315^{\circ} \mathrm{C}\right)\end{array}$ & Silwer & 0.15 \\
\hline & $\begin{array}{l}\text { N-1000"' High Purity } \\
\text { Anti-Seize }\end{array}$ & $\begin{array}{l}51115 \\
51116 \\
51117\end{array}$ & $\begin{array}{l}8 \text { or. brush-top can } \\
1 \text { lb. can } \\
2 \text { lb. can }\end{array}$ & $\begin{array}{l}1800^{\circ} \mathrm{F} \\
\left(982^{\circ} \mathrm{C}\right)\end{array}$ & Copper & 0.17 \\
\hline
\end{tabular}


SRNL-STI-2008-00544, REVISION 0

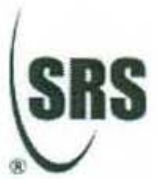

Eric Skidmore/SRNL/Srs

05/22/2007 01:38 PM
To James Gee/WSRC/Srs@Srs

cc Daniel Krementz/SRNL/Srs@Srs

bcc

Subject Re: Fw: O-ring lubricants [

The Molykote 55 product appears to be a stearate-based silicone grease (most Dow products are silicones) which should be highly compatible with Viton, particularly for the application in mind. Silicone oils and greases in general are very compatible with Viton (worst combination is silicone grease on silicone O-rings, like dissolves like problem, same for hydrocarbons and EPDM). A little swelling is acceptable and usually normal (5-10\%). We use Dow-Corning High Vacuum silicone grease on Viton GLT O-rings in the 9975 shipping container and I do not know of any compatibility problems.

The problem with the other product (anti-seize) was a question on the lead oxide compatibility with the Viton (as I recall). The Molykote 55 appears to be a safer choice. Not sure if the O-ring or lubricant will see any direct chemical exposure, but silicones are not highly resistant to acids or strong bases. If only in the surrounding environment (nitric used for decon, etc.), the silicone should be fine.

The best bet for compatibility is to use a product recommended by the O-ring manufacturer (Parker, etc.) if possible, but they usually also recommend end-user testing so not always practical.

\section{Eric Skidmore}

SAVANNAH RIVER NATIONAL LABORATORY

Materials Science \& Technology

Phone: 803-725-2236

FAX: 803-725-1744

James Gee/WSRC/Srs

James Gee/WSRC/Srs

05/22/2007 01:12 PM
To Eric Skidmore/SRNL/Srs@Srs

ccDDaniel Krementz/SRNL/Srs@Srs

Subject Fw: O-ring lubricants

Eric,

Dan has proposed using Molykote $55 \mathrm{O}$-ring lubrication for the remote gasket replacement tooling. $\mathrm{He}$ was a little concerned about its suitability with Viton. I looked up a spec sheet for this product and for a room temperature application (assumed), it looks acceptable (i.e., relatively stable) with Viton. What are your thoughts? Do you have another recommendation. Feel free to contact Dan directly is you need more specific information on the application.

- Forwarded by James Gee/WSRC/Srs on 05/22/2007 01:05 PM --_-

Daniel Krementz/SRNL/Srs

05/11/2007 02:45 PM

To James Gee/WSRC/Srs@Srs

cc

Subject Re: O-ring lubricants 
$\operatorname{Jim}$,

Per the message below, I have some Dow-Corning Molykote 55 o-ring lube. Do you know if this product is acceptable?

Thanks,

Dan Krementz

Development Engineer

Savannah River National Laboratory

Robotics, Remote \& Specialty Equipment

Building 723-A, Savannah River Site

Phone: 803-725-2410

Page: 803-725-7243, ID\# 10758

Daniel Krementz/SRNL/Srs

Daniel Krementz/SRNL/Srs

05/11/2007 12:47 PM

\author{
To James Gee/WSRC/Srs \\ cc \\ Subject O-ring lubricants
}

Jim,

The anti-seize compound that I am using on the gasket installation tool is mildly incompatible with Viton . Do you have a list of silicone based o-ring lubes that are approved for DWPF use?

Thanks,

Dan Krementz

Development Engineer

Savannah River National Laboratory

Robotics, Remote \& Specialty Equipment

Building 723-A, Savannah River Site

Phone: 803-725-2410

Page: 803-725-7243, ID\# 10758 